\title{
A Preliminary Investigation on Methods of Reducing Antibiotic Resistant Bacteria in Broiler Litter in Selected Farms in Mid Country, Sri Lanka
}

\author{
E.M. Herath, W.S. Dandeniya ${ }^{1 *}$, A.G.S.I. Samarasinghe ${ }^{2}$, T.P.M.S.D.Bandara ${ }^{2}$ and \\ R.N. Jinadasa ${ }^{2}$
}

Postgraduate Institute of Agriculture

University of Peradeniya

Sri Lanka

\begin{abstract}
Antibiotic residues and bacteria resistant to antimicrobial have been found in poultry litter, which is popular low cost manure in agriculture. A study was conducted to investigate a pre-treatment method to reduce antibiotic resistant bacteria in poultry litter. Poultry litter was collected from eleven medium-scale broiler farms in Kandy. Total and antibiotic resistant (tetracycline and/or enrofloxacin) culturable bacteria were isolated using Tryptic Soy Agar supplemented with 0 or 100 ppm of each antibiotic. A fresh and a cured broiler litter sample were collected from one farm and treated with different temperatures $\left(25^{\circ} \mathrm{C}, 40^{\circ} \mathrm{C}, 60^{\circ} \mathrm{C}\right.$ and $80^{\circ} \mathrm{C}$ for 24 hours), neem seed extract (10 and 1000 ppm for 4 day) and neem dry leaves $(10 \% \mathrm{w} / \mathrm{w}$ for 4 days) in triplicates. Total and antibiotic resistant bacteria in treated litter were assessed. Broiler litter from all farms contained tetracycline resistant bacteria. Heating at $80{ }^{\circ} \mathrm{C}$ reduced tetracycline resistant bacteria by $96-100 \%$ compared to $25^{\circ} \mathrm{C}$. Neem seed extract at $10 \mathrm{ppm}$ reduced tetracycline resistant bacteria by $75-96 \%$. Treating broiler litter with high temperature $\left(>60^{\circ} \mathrm{C}\right)$ and neem seed extract $(10$ ppm) could minimize spread of antibiotic resistant bacteria to the environment.
\end{abstract}

Keywords: Antibiotic resistant bacteria, broiler litter, Enrofloxacin, Tetracycline

\section{INTRODUCTION}

Extensive use of antibiotics in animal husbandry may cause widespread allergic reactions and antibiotic resistance among human pathogens. In Sri Lanka nearly 94 MT of chicken meat is supplied yearly by poultry farms managed intensively, where use of antibiotics is a common practice (FAO, 2012). In poultry industry antibiotics are used excessively as therapeutic and sub- therapeutic measures (Donoghue, 2003). Enrofloxacin, amoxicillin and sulphadiazine are the most frequently used antibiotics in animal husbandry in Sri Lanka. Most of the antimicrobials and some antibiotic resistant gutflora end up in waste products created in poultry production including poultry litter (Diarrassouba et al., 2007; Chen and Jiang, 2014). From antibiotics used with diet 3 to $60 \%$ is excreted generally and concentrations in litter could range from 0.2 to $66 \mathrm{mg} / \mathrm{kg}$ (Furtula, et al., 2010). A number of studies suggest poultry litter could act as carriers for antimicrobials and antibiotic resistant organisms in the environment (Furtula, et al., 2010; You et al., 2012; Chen and Jiang, 2014).

\footnotetext{
Department of Soil Science, Faculty of Agriculture, University of Peradeniya, Sri Lanka

Faculty of Veterinary Medicine \& Animal Science, University of Peradeniya, Sri Lanka

Corresponding author: warshisd@pdn.ac.lk
} 
Pretreating poultry litter could be a solution to reduce antibiotic resistant organism in litter (Chen and Jiang, 2014). Composting poultry litter, applying chemicals like $\mathrm{CaO}$ and introducing insect larvae as biological control agents have been tested as methods to reduce antibiotic resistant pathogenic bacteria populations in litter with varying success (Chen and Jiang, 2014). The aim of the present study was to determine the effect of subjecting broiler litter for heat treatment or incubation with seed extract or leaves of Azadiracta indica, a plant well known for its biocide properties, on antibiotic resistant bacteria as a preliminary investigation to identify pre-treatment method for broiler litter.

\section{METHODOLOGY}

\section{Sampling of poultry litter}

The study was conducted using 11 medium scale broiler farms (each rearing about 2,000 birds per flock) located in Kandy district (Mid-Country Wet Zone), Sri Lanka. A questionnaire was given to the broiler farmers and information were gathered about antibiotic usage in their farm, waste management and manure production. All farmers participated in the study maintained one flock of birds until the batch was 42 days old and removed the bedding material once the broilers were sold. The common practice was to sell litter directly to litter collectors, who sell it to vegetable growers. However, some farmers in the region treated the removed litter with commercially available microbial inoculants called Mizuho ${ }^{\circledR}$, and pile it and cure for three months before selling as manure (referred to as cured litter hereafter). Composite samples were collected from freshly removed litter and cured litter (when available) from each farm. Litter samples were brought to the laboratory and stored at $4^{\circ} \mathrm{C}$ until analysis.

\section{Antibiotic resistant bacteria in poultry litter}

Total and antibiotic resistant populations of culturable bacteria in the freshly removed and cured litter samples were cultured using ten-fold serial dilution technique in spread plate method. Tryptic Soy Agar (TSA) was used to grow total culturable bacteria and TSA supplemented with tetracycline, enrofloxacin and combination of both antibiotics (each at $100 \mathrm{ppm}$ ) were used to isolate the antibiotic resistant bacteria (You et al., 2012). Antibiotic resistance screening level at $100 \mathrm{ppm}$ was selected after preliminary investigations using 10 , 100 and $1000 \mathrm{ppm}$ as test levels. Plates were incubated in dark at $27^{\circ} \mathrm{C}$ for $48 \mathrm{~h}$ and colony forming units (CFU) were counted. Selected isolates were subcultured to TSA containing plates and purified strains were used in Gram staining and antibiotic sensitivity testing (ABST) against enrofloxacin $(10 \mu \mathrm{g})$, gentamycin $(10 \mu \mathrm{g})$, neomycin $(30 \mu \mathrm{g})$, augmentin $(30 \mu \mathrm{g})$ and tetracycline $(30 \mu \mathrm{g})$ by disk diffusion method (Diarrassouba et al., 2007).

\section{Evaluating pre-treatment methods}

A fresh litter sample and cured litter sample (cured for 3 months after applying a commercially available Effective Microbial mixture by farmer) collected from the same farm were used in the experiment on pre-treatment methods. Electrical conductivity (EC) and $\mathrm{pH}$ (both in 1:5, litter: water suspension) of litter were determined after pre-treatments. 


\section{Heat treatment}

Poultry litter was arranged in metal trays as layers of $3 \mathrm{~cm}$ deep and subjected to $25^{\circ} \mathrm{C}, 40$ ${ }^{\circ} \mathrm{C}, 60{ }^{\circ} \mathrm{C}$ and $80{ }^{\circ} \mathrm{C}$ for 24 hours in triplicates using drying ovens. At the end of the heat treatment total and antibiotic resistant (towards tetracycline and/or enrofloxacin) bacteria were cultured.

\section{Incubating litter with Azadirachta indica (neem) seeds and leaves}

Dry A. indica seed were finely ground and mixed with sterilized distilled water (Al-Hazmi, 2013). A. indica seed extract was mixed with poultry litter samples to achieve final concentrations of 10, 100 and $1000 \mathrm{ppm}$ (mg of seeds per kg of litter in dry weight basis) in triplicates. Litter mixed with dry A. indica leaves $(10 \% \mathrm{w} / \mathrm{w})$ was also included as a treatment and unamended litter served as the control. Treated litter and control were incubated for 7 days and cumulative respiration during 0 to 4 and 4 to 7 days were measured using soda lime trap method (Anderson and Ingram, 1989). Total culturable and bacteria resistant to tetracycline and/or enrofloxacin $\left(100 \mathrm{ppm}\right.$ each) at $4^{\text {th }}$ day of the incubation were plated using TSA medium as described previously.

\section{Data analysis}

Significance of treatments was analyzed by analysis of variance (ANOVA) in General Linear Model (GLM) procedure at $\mathrm{p}<0.05$ level. Means were compared using Tukey method $(\mathrm{p}<0.05)$. MINITAB version 16 software was used in data analysis.

\section{RESULTS AND DISCUSSION}

As revealed by questionnaire survey all broiler farmers participated in the study use antibiotics as a sub therapeutic measure. They all give antibiotics to farm animals via drinking water. Tetracycline, enrofloxacin and amoxicillin are the most common antibiotics used by farmers participated in the study. Farmers treat the flock with one or two of these antibiotics during the first three weeks of broilers. The antibiotic treatment frequency depends on farmers' perception on likelihood of spreading diseases and none of the farmers consulted a veterinary surgeon before treating the flock with antibiotics. Immediately after one batch of broiler chicken is sold, the litter is removed. Three categories of litter handling practices exist among farmers in Kandy district were identified by the present study: 1. Immediately selling litter to litter buyers, 2. Burning of litter on-site, and 3. Curing after treating litter with "Mizuho", a commercially available microbial inoculant (an effective microbial mixture)

Total culturable bacteria population in freshly removed broiler litter samples ranged from 7.079 to $7.771 \log \mathrm{CFU} \mathrm{g}{ }^{-1}$ dry litter. In comparison to total culturable population more than 100 fold decrease in bacteria population size was observed on TSA plates supplemented with $100 \mathrm{ppm}$ of each tetracycline (4.681 to $5.279 \log$ CFU g${ }^{-1}$ dry litter), enrofloxacin (4.146 to $5.112 \log$ CFU g ${ }^{-1}$ dry litter), and both antibiotics (2.944 to $5.029 \log$ CFU g ${ }^{-1}$ dry litter). Four bacteria strains isolated from freshly removed litter showed resistance towards at least two antibiotics. According to Graham et al. (2009) antibiotic resistance could disperse from poultry houses into the environment via houseflies. Due to presence of antibiotic resistant bacteria there is a risk of contaminating agricultural soils when poultry litter is used as a fertilizer to crops (Chen and Jiang, 2014). 
Total culturable and antibiotic resistant bacteria were significantly higher in cured litter than freshly removed litter (Table 1). Enrofloxacin resistant bacteria and those resistant to both enrofloxacin and tetracycline were present only in cured litter (Table 1). With increasing temperature both total bacteria and antibiotic resistant bacteria populations declined. Heating at $80^{\circ} \mathrm{C}$ reduced tetracycline resistant bacteria population size by $96-100 \%$ compared to the resistant bacteria population at $25^{\circ} \mathrm{C}$. Similarly neem seed extract at $10 \mathrm{ppm}$ reduced tetracycline resistant bacteria by $75-96 \%$. When the total culturable bacteria population in broiler litter is large, there is more chance of finding tetracycline resistant bacteria $(r=0.61)$. The highest suppression of antibiotic resistant bacteria in broiler litter was observed in $80{ }^{\circ} \mathrm{C}$ followed by $60^{\circ} \mathrm{C}$. Incubating with $10 \mathrm{ppm} A$. indica seed extract suppressed antibiotic resistant bacteria population but did not affect total culturable bacteria population size (Table 1). Poultry litter can be pretreated to minimize spread of antibiotic resistant bacteria to environment (Chen and Jiang, 2014). Pre-treatments used in the present study affected the chemical properties ( $\mathrm{pH}$ and EC) of litter, which may have contributed to the observed differences in bacteria populations in addition to the direct effect of treatments on microbial cells (Table 1).

Table 1. The effect of treating broiler litter with heat and incubating with Azadirachta indica seed extract (ASE) on biological and chemical properties

\begin{tabular}{|c|c|c|c|c|c|c|c|c|}
\hline \multirow{2}{*}{$\begin{array}{c}\text { Litter } \\
\text { type }\end{array}$} & \multirow{2}{*}{\multicolumn{2}{|c|}{ Treatment }} & \multicolumn{4}{|c|}{$\begin{array}{c}\text { *Culturable bacteria (log CFU/g } \\
\text { dry litter) }\end{array}$} & \multirow{2}{*}{ pH } & \multirow{2}{*}{$\begin{array}{c}\mathbf{E C} \\
(\mu \mathrm{s} / \mathrm{cm})\end{array}$} \\
\hline & & & No & T100 & E100 & TE100 & & \\
\hline \multirow{7}{*}{$\begin{array}{l}\text { Freshly } \\
\text { remove } \\
\text { d litter }\end{array}$} & Control & $\mathrm{RT}^{\dagger}$ & $6.88^{\mathrm{a}}$ & $5.20^{\mathrm{ab}}$ & $\mathrm{ND}^{\ddagger}$ & ND & $9.1^{\mathrm{a}}$ & $3190^{\mathrm{a}}$ \\
\hline & Heat & $25^{\circ} \mathrm{C}$ & $7.08^{\mathrm{a}}$ & $5.49^{\mathrm{a}}$ & ND & ND & $9.0^{\mathrm{a}}$ & $4110^{\mathrm{a}}$ \\
\hline & & $40^{\circ} \mathrm{C}$ & $7.34^{\mathrm{a}}$ & $5.53^{\mathrm{a}}$ & ND & ND & $7.7^{\mathrm{ab}}$ & $3425^{\mathrm{a}}$ \\
\hline & & $60^{\circ} \mathrm{C}$ & $6.21^{\mathrm{ab}}$ & $4.20^{c}$ & ND & ND & $7.3^{\mathrm{ab}}$ & $3910^{\mathrm{a}}$ \\
\hline & & $80^{\circ} \mathrm{C}$ & $5.02^{b}$ & $4.02^{\mathrm{c}}$ & ND & ND & $6.8^{\mathrm{b}}$ & $5210^{\mathrm{a}}$ \\
\hline & ASE & $10 \mathrm{ppm}$ & $7.13^{\mathrm{a}}$ & $4.06^{\mathrm{c}}$ & ND & ND & $9.0^{\mathrm{a}}$ & $3165^{\mathrm{a}}$ \\
\hline & & $1000 \mathrm{ppm}$ & $7.46^{\mathrm{a}}$ & $4.47^{\mathrm{bc}}$ & ND & ND & $8.4^{\mathrm{ab}}$ & $2990^{\mathrm{a}}$ \\
\hline \multirow{7}{*}{$\begin{array}{l}\text { Cured } \\
\text { litter }\end{array}$} & Control & $\mathrm{RT}$ & $6.83^{\mathrm{b}}$ & $5.57^{\mathrm{a}}$ & $5.60^{\mathrm{a}}$ & $5.57^{\mathrm{a}}$ & $7.9^{\mathrm{a}}$ & $1567^{b}$ \\
\hline & Heat & $25^{\circ} \mathrm{C}$ & $7.32^{\mathrm{a}}$ & $5.40^{\mathrm{a}}$ & $5.52^{\mathrm{a}}$ & $5.49^{\mathrm{a}}$ & $7.2^{\mathrm{a}}$ & $2645^{\mathrm{ab}}$ \\
\hline & & $40^{\circ} \mathrm{C}$ & $6.48^{\mathrm{bc}}$ & $3.32^{\mathrm{c}}$ & $3.23^{\mathrm{c}}$ & $2.93^{\mathrm{c}}$ & $7.2^{\mathrm{a}}$ & $3710^{\mathrm{a}}$ \\
\hline & & $60^{\circ} \mathrm{C}$ & $6.01^{\mathrm{d}}$ & $3.04^{c}$ & $2.40^{\mathrm{d}}$ & $2.34^{\mathrm{d}}$ & $7.2^{\mathrm{a}}$ & $3715^{\mathrm{a}}$ \\
\hline & & $80^{\circ} \mathrm{C}$ & $4.18^{\mathrm{e}}$ & ND & ND & ND & $7.2^{\mathrm{a}}$ & $3485^{\mathrm{a}}$ \\
\hline & ASE & $10 \mathrm{ppm}$ & $6.27^{\mathrm{cd}}$ & $4.66^{\mathrm{b}}$ & $4.82^{\mathrm{b}}$ & $3.81^{\mathrm{b}}$ & $8.3^{\mathrm{a}}$ & $1579^{\mathrm{b}}$ \\
\hline & & $1000 \mathrm{ppm}$ & $6.71^{\mathrm{b}}$ & $4.28^{\mathrm{b}}$ & $4.56^{\mathrm{b}}$ & $4.10^{\mathrm{b}}$ & $8.0^{\mathrm{a}}$ & $1547^{\mathrm{b}}$ \\
\hline
\end{tabular}

Mean in a given column followed by the same letter not significantly different for a given litter type (p<0.05)

*Bacteria appeared on plates amended with, no antibiotic - 0 ppm antibiotic, T100 - 100 ppm Tetracycline, E100 -

100 ppm Enrofloxacin and TE100 - 100 ppm each of Tetracycline and Enrofloxacin.

${ }^{\dagger} \mathrm{RT}=$ Broiler litter kept at room temperature

${ }^{\ddagger} \mathrm{ND}$ - not detected

Respiration rate of freshly removed broiler litter was significantly higher than respiration rate of cured litter (Fig. 1). Incubating with A. indica seed extracts at $10 \mathrm{ppm}$ level significantly reduced respiration while seed extracts at $100 \mathrm{ppm}$ and above and incubating with neem leaves significantly enhanced respiration. However, the culturable bacteria population in soils treated with neem seed extracts were not affected by the concentrations used. Neem 
extracts may have suppressed the activity of microorganisms but may have less effect on cell viability. According to Al-Hazmi (2013) A. indica can successfully reduce the growth of some plant pathogens. A. indica has antibacterial property due to the presence of nimbidin, nimbolide, mahmoodin, margolone, margolonone and isomargolonone (Bhowmik et al., 2010). Since the growth of total and antibiotic resistant bacteria population in litter were suppressed by $A$. indica extract (Table 1) this could be suggested as a low cost litter treatment method for farmers.

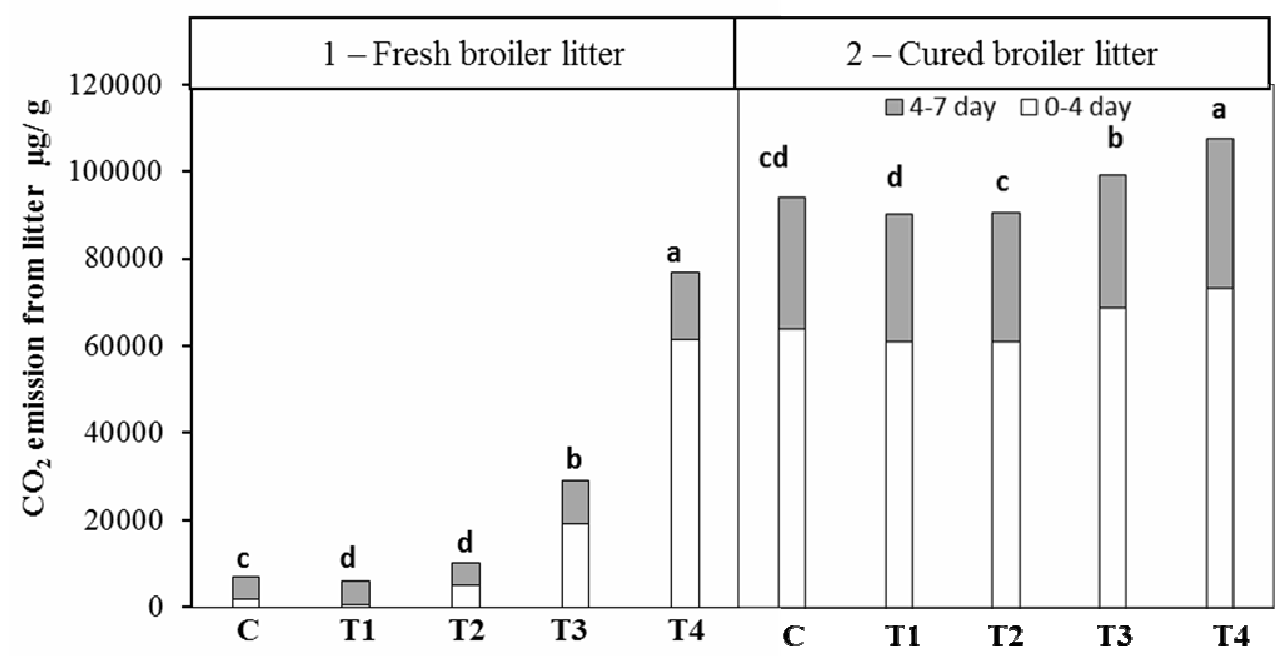

Fig.1. Cumulative respiration over 7 days (white bars - 0 to 4 days and grey bars -4 to 7 days) of incubation of freshly removed broiler litter (1) and cured litter (2) with $A$. indica seed extraction (ASE) and dry leaves

C- control, T1- 10ppm ASE,T2- 100ppm ASE, T3-1000ppm ASE and T4- dry leaves at 10\% (w/w). In a given litter type vertical bars followed by same letter are not significantly different.

Differences in initial composition of litter, moisture contents, temperature levels achieved and treated duration are known to affect the degree of destruction of antibiotic resistant pathogenic bacteria populations during composting and direct heating techniques (Chen and Jiang, 2014). The present study also indicate heating or treating the litter with a natural biocide like neem tissue extracts differently affect the antibiotic resistant bacteria in broiler litter based on litter type (freshly removed vs. cured litter) and the strength of the treatment (heating temperature or neem extract type and concentration).

\section{CONCLUSIONS}

Broiler litter harbored tetracycline and/or enrofloxacin resistant bacteria. The effect of pretreatment of broiler litter on antibiotic resistant bacteria populations depend on initial characters of the litter. Heating poultry litter at $80^{\circ} \mathrm{C}$ could suppress antibiotic resistant populations in litter followed by heating at $60^{\circ} \mathrm{C}$ and incubating with neem seed extracts at $10 \mathrm{ppm}$ concentration. 


\section{ACKNOWLEDGEMENT}

Financial support from International Foundation for Science grants-2012 is acknowledged.

\section{REFERENCES}

Al-Hazmi, R.H.M. (2013). Effect of Neem (Azadirachta indica) leaves and seeds extract on the growth of six of the plant disease causing fungi. Glo. Adv. Res. J. Microbiol., 2(5), 89 98.

Anderson, J.M., Ingram, J.S. (1989) Tropical soil biology and fertility, A Handbook of methods, C.A.B. International.

Bhowmik, D., Chiranji, B., Yadav. J., Tripathi, K.K. and SampathKumar, K.P.J. (2010). Herbal remedies of Azadirachta indica and its medicinal application. J. Chem. Pharm. Res., 2(1), $62-72$.

Chen, Z. and Jiang, X. (2014). Microbiological safety of chicken litter or chicken litter based organic fertilizers. Agriculture., 4, 1 - 29.

Diarrassouba, F., Diarra, M.S., Bach, S., Delaquis, P., Pritchard, J., Topp, E. and Skura, B.J. (2007). Antibiotic resistance and virulence genes in commensal Escherichia coli and Salmonella isolates from commercial broiler chicken farms. J Food Prot., 70, 1316 1327.

Donoghue, D.J. (2003). Antibiotic residues in poultry tissues and eggs: human health concerns. Poult Sci., 82, 618 - 621.

Furtula, V., Farrell, E.G., Diarrassouba, F., Rempel, H., Pritchard, J. and Diarra, M.S. (2010).Veterinary pharmaceuticals and antibiotic resistance of Escherichia coli isolates in poultry litter from commercial farms and controlled feeding trials. Poult Sci., 89, 180 - 188.

Food and Agriculture Organization of the United Nations-FAO(2012).Proceedings of the International Workshop on the Use of Antimicrobials in Livestock Production and Antimicrobial Resistance in the Asia-Pacific Region.

Graham, P.J., Price, L.B., Evans, S.L., Graczyk, T.K. and Silbergeld, E.K. (2009). Antibiotic resistant enterococci and staphylococci isolated from flies collected near confined poultry feeding operations. Sci Total Environ., 407(8), 2701 - 2710.

You, Y., Hilpert, M. and Ward. M.J. (2012). Detection of a common and persistent tet chicken-waste-impacted farm soil. Appl Environ Microbiol., 78(9), 3203. 